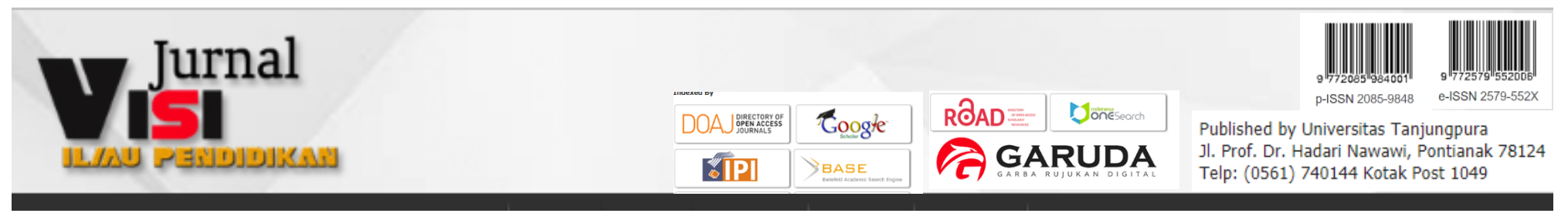

\title{
MEMAKSIMALKAN KEMAMPUAN MENELUSUR PADA PORTAL E-RESOURCES PERPUSTAKAAN NASIONAL RI
}

\author{
Atiqa Nur Latifa Hanum \\ Program Studi D-3 Perpustakaan, Universitas Tanjungpura, Pontianak \\ atiqa.nur@fkip.untan.ac.id.
}

\begin{abstract}
Searching for information can be done simply (basic) or complex. Its depends on the level of ability of the information seeker. The study was to describe the relationship between the ability to search and the relevance of search results on the e-resources portal of the National Library of Indonesia (PNRI) so that it can find ways to maximize the ability to search for scientific digital information sources on that portal. The method used was quantitative with descriptive statistics analysis. The technique of colleting data was questionnaires, interviews, and literature studies. For the population, there were 108 active students of D-3 Library Science Study Program in the FKIP, while the sample was D-3 Library Science Study Program students who have accessed e-resources services of PNRI with the numbers 45 students who are considered representative in terms of search capabilities. The results showed that there was a relationship between the ability of students in searching and e-resources database of PNRI with the relevance of search results. It can be seen from the suitability of journal articles and electronic books that they were searching. 78,05\% of students were able to search and got relevant results because they were influenced by the selection strategy of the search strategy. The effectiveness of strategy selection was also influenced by the ability to break down or formulate keywords. In these study, the ability to formulate keywords as the basis of search was in the low category, but the combination to get the needed information was in the high category.
\end{abstract}

Keywords: searching for information, e-resources, National Library of Indonesia

\section{PENDAHULUAN}

Informasi menjadi salah satu komoditas penting yang bernilai guna bagi kesejahteraan hidup manusia. Informasi diproduksi setiap harinya, dikemas dalam berbagai bentuk media, dan disebarluaskan dengan berbagai cara dan kecepatan. Namun, informasi yang beredar tidak semuanya memenuhi kriteria informasi yang berkualitas, artinya informasi yang beredar dari berbagai sumber perlu dievaluasi sebelum dipergunakan oleh pengguna informasi terutama informasi yang ada di internet. Oleh sebab itu, pentingnya memilih dan mengevaluasi sumber informasi yang tepat menjadi suatu keharusan agar kebenaran nilai informasinya terjamin dan aman dipergunakan.
Mayoritas pengguna informasi di internet adalah para generasi digital dan milenial yang mana untuk memenuhi kebutuhan dasarnya seperti kebutuhan kognitif, afektif, integrasi personal, integrasi sosial, hingga berkhayal bisa mereka dapatkan dengan mudah melalui sumbersumber informasi yang ada di internet. Akan tetapi yang menjadi perhatian di sini, yakni pemenuhan kebutuhan kognitif seseorang, misalnya menelusur informasi untuk mendapatkan sumber informasi yang kredibel guna kepentingan belajar.

Untuk menunjang kelancaran dalam proses belajar, secara sadar maupun tidak sadar seseorang akan membutuhkan informasi. Demi menunjang kelancaran tersebut, baik pemerintah,

website: http://jurnal.untan.ac.id/index.php/jvip email: jurnalvisi@untan.ac.id 
DOI: 10.26418/jvip.v11i2.33040

lembaga pendidikan, tenaga pendidik, maupun pustakawan bersinergi memfasilitasi para generasi digital dan milenial serta memandang mereka sebagai generasi pembelajar yang perlu diberikan wadah ilmiah agar mempermudah mereka dalam belajar. Permasalahannya sekarang, tidak semua generasi pembelajar sekalipun mahasiswa memiliki kemampuan menelusur informasi dan menemukan sumber informasi yang relevan dengan kebutuhannya. Oleh karena itu, dengan menyediakan unit pelayanan teknis perpustakaan perguruan tinggi, ruang baca, hingga pada beberapa link alternatif untuk akses koleksi digital merupakan solusi terbaik agar mereka dapat mengkonsumsi informasi yang berkualitas dan tidak diragukan keilmiahannya.

Misalnya, pemerintah melalui Perpustakaan Nasional Republik Indonesia menyediakan fasilitas berupa portal untuk akses koleksi digital baik berupa buku maupun jurnal elektronik yang dapat diakses pada laman portal eresources.perpusnas.go.id. Ruang lingkup subjek yang dimiliki bervariatif bergantung pada vendor jurnal yang dilanggan oleh perpustakaan nasional. Namun agar informasi yang diinginkan dapat segera ditemukan dan relevan dengan kebutuhan maka perlunya kemampuan dalam penelusuran informasi.

\section{METODE PENELITIAN}

Metode penelitian ini adalah kuantitatif dengan analisis deskriptif yang berusaha memaparkan secara kuantitatif kemampuan menelusur informasi. Sampel penelitian ini sebanyak 45 orang. Teknik pengambilan sampel diambil secara purposive sampling dikarenakan sampel pada penelitian ini harus memiliki pengalaman mengakses portal e-resources dan telah mempelajari strategi penelusuran sebelumnya sebagai kemampuan lanjutan penelusuran. Analisis data menggunakan aplikasi SPSS 25. Penelitian ini menggunakan metode kuantitatif karena bermaksud menguji teori tertentu dengan cara meneliti hubungan antarvariabel yang mana pada penelitian ini ada
Vol 11, No 2 (2019)- Atiqa Nur Latifa Hanum

tiga variabel yang digunakan yaitu Kemampuan Menelusur $\left(\mathrm{X}_{1}\right)$ dan pangkalan data $\left(\mathrm{X}_{2}\right)$ sebagai variabel bebas (independen) dan Relevansi (Y) sebagai variabel terikat (dependen). Variabelvariabel ini diukur dengan perhitungan statistik untuk mereduksi kemungkinan adanya bias sehingga data-data lapangan yang terkumpul dapat dianalisis dan disajikan dengan baik. Kemampuan menelusur memiliki indikator strategi penelusuran dan merumuskan kata kunci. Pangkalan data memiliki indikator titik akses dan jenis koleksi. Sedangkan relevansi memiliki indikator manfaat umpan balik, manfaat prediktif, dan kelengkapan.

\section{HASIL DAN PEMBAHASAN}

Generasi digital native ditandai dengan kecenderungan sikap yang memiliki rasa keingintahuan yang besar terhadap sesuatu jadi mereka lebih bersifat mencari, interaktif, berkolaborasi, ekspresif, dan suka berinteraksi dengan dunia digital. Hasil penelitian ini membuktikan bahwa mereka yang terlahir pada usia muda atau tergolong pada generasi digital native memang menyukai dan sering mengakses data online. Begitu pula dalam belajar, mereka lebih menyukai informasi yang didapatkan secara cepat sambil diikuti dengan aktivitas lain. Artinya mereka bersifat multi tasking, mengerjakan banyak hal dalam satu waktu. Mereka mengakses sumber informasi online sebagai kebutuhan referensi mereka.

Informasi yang tersebar secara bebas pada internet tidak menjamin bahwa informasi yang ada berkualitas.Tidak jarang seseorang yang belum melek terhadap informasi dan media akan mengkonsumsi informasi yang tidak bernilai. Dengan kata lain informasi ringan yang tidak bermanfaat bagi kehidupan seseorang. Tentu saja untuk dapat berselancar di internet, maka seseorang harus memiliki kemampuan menelusur informasi. Hughes (dalam Suadi dan Makmur, 2015:22) menerangkan bahwa ada kemampuan yang harus dimiliki para pencari informasi di era digital yakni tool literacy dan resources literacy. Tool literacy berarti 
seseorang harus mampu menggunakan alat telusur, yang dapat berupa online catalogue ataupun melalui pangkalan data di internet. Ketika seseorang akan melakukan penelusuran maka hal yang dapat ia lakukan adalah menggunakan strategi penelusuran untuk mengefektifkan dan mengefisienkan proses penelusuran. Selain itu bisa diimbangi pula dengan merumuskan kata kunci pencarian yang tepat pada tool box searching di setiap pangkalan data yang dipilih untuk mendapatkan sumber sesuai kebutuhan.

T.B Wilson menggambarkan perilaku sehari-hari individu dalam menelusur informasi dengan manifestasi keyakinan, nilai, dan norma. Model teori perilaku pencarian informasi milik T.B Wilson menerangkan beberapa tahapan yakni (1) memulai, (2) menghubungkan, (3) merambah, (4) memilah, (5) memantau, (6) merangkum, (7) verifikasi, dan (8) penyelesaian (Laksmi dan Fauziah, 2016: 56). Pada tahapan nomor ketiga yakni merambah merupakan tahapan yang membutuhkan kemampuan yang akan memperlancar seseorang hingga pada proses akhir, yakni penyelesaian atau dalam penggunaan informasi. Kegiatan merambah dalam menelusur informasi dapat dilakukan secara semi terstruktur, baik dengan membaca dari suatu bacaan atau dengan cara bertanya kepada orang yang dianggap memiliki kapabilitas menjawab perihal yang ingin diketahuinya. Namun yang akan dibahas di sini adalah merambah dalam menelusur informasi menggunakan layanan e-resources milik Perpustakaan Nasional RI.

Layanan e-resources perpustakaan nasional RI (PNRI) merupakan salah satu layanan berbasis digital dimana setiap masyarakat dapat mengakses layanan ini secara gratis, bahkan mengunduh koleksi dari pangkalan data jurnal dan buku yang dilanggan oleh pemerintah RI. Sosialisasi pemanfaatan layanan ini telah dilakukan, banyak yang telah mengetahui adanya fasilitas ini sehingga masyarakat umum maupun pembelajar dapat memanfaatkan seluruh koleksi yang ada. Tentu saja mengakses informasi melalui layanan ini akan berbeda dengan menelusur informasi secara bebas di internet.

Informasi yang ada di internet masih membutuhkan tinjauan ulang dan sejumlah evaluasi untuk mendapatkan sumber informasi yang berkualitas. Ada delapan kriteria yang dapat digunakan untuk menentukan nilai kualitas dari suatu informasi berdasarkan pendapat Lippeveld, Sauborn, dan Bodart yang dikutip oleh Hartono (2013:17-18) meliputi relevansi, kelengkapan atau keluasan, kebenaran, terukur, keakuratan, kejelasan, keluwesan, dan ketepatan waktu. Oleh sebab itu, pentingnya memilih dan mengevaluasi sumber informasi yang tepat menjadi suatu keharusan agar informasi yang dibutuhkan dapat terjamin kualitas isinya.

Untuk lebih jelasnya, relevansi berarti seberapa jauh tingkat kesesuaian informasi tersebut dengan kenyataan kejadian di masa lalu, kejadian hari ini, dan kejadian yang akan datang kemudian membentuk aktivitas yang konkrit dan mampu dilaksanakan serta dibuktikan oleh siapa saja. Kelengkapan dan keluasan, artinya informasi tersampaikan secara menyeluruh, dengan lengkap dan benar karena jika informasi yang diterima hanya sebagian akan mempengaruhi dalam pengambilan keputusan. Kebenaran, artinya informasi disajikan secara jujur atau mengandung nilai-nilai kebenaran yang menggambarkan hubungan realitas yang ada. Terukur, artinya informasi dapat diukur dari segi manfaat dan biaya untuk mendapatkannya. Keakuratan, artinya informasi mencerminkan keadaan yang sebenarnya dan bebas dari kesalahan-kesalahan. Kejelasan, artinya informasi diperoleh dari sumber yang dapat dipercaya, disampaikan dengan kalimat yang sederhana namun mampu memberikan makna dan hasil yang mendalam bagi siapapun yang menerimanya. Keluwesan (flexibility), artinya informasi dapat dimanfaatkan dan membantu untuk berbagai kebutuhan. Ketepatan waktu berarti informasi tersampaikan pada waktu yang sama atau tepat pada saat siapapun membutuhkannya untuk menunjang aktivitasnya. 
Dengan demikian, ketika seseorang ingin memperoleh sumber informasi yang relevan maka perlunya memiliki kemampuan menelusur informasi dan menentukan lokasi akses yang tepat. Kemampuan menelusur berarti membicarakan strategi penelusuran maupun merumuskan kata kunci. Penelitian ini menunjukkan bahwa 78,05 \% responden menggunakan strategi penelusuran saat mencari informasi pada portal e-resources. Hanya sebesar $22 \%$ saja yang tidak menggunakan strategi penelusuran saat mencari informasi di internet. Berikut data mengenai strategi penelusuran yang banyak digunakan berdasarkan responden penelitian ini:

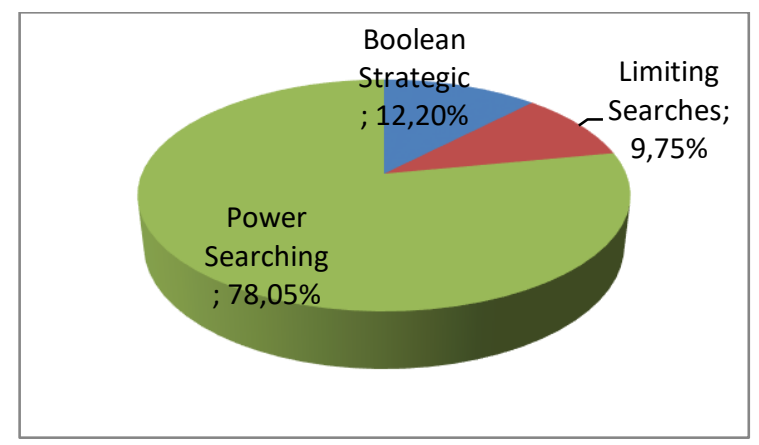

\section{Gambar 1. Grafik jenis Strategi yang digunakan responden}

Dengan menggunakan strategi penelusuran dapat memperbesar kemungkinan untuk mendapatkan sumber yang sesuai kebutuhan dibandingkan tidak menggunakan strategi. Waktu yang dibutuhkan untuk menelusur lebih singkat dan cepat jika menggunakan strategi penelusuran karena sumber informasi yang terpanggil menyesuaikan strategi yang digunakan. Misalnya saat melakukan penelusuran, seseorang menggunakan strategi boolean yakni penggunaan AND, OR, dan NOT. Semua kata yang mengandung kata kemudian dikombinasikan dengan ketiga logika boolean tersebut akan terpanggil maka akan mempersempit temuan dan memudahkan untuk mengevaluasi sumber informasi yang ditemukan saat merambah sumber elektronik. Di sisi lain, yakni 9 orang responden tidak menggunakan strategi penelusuran saat mencari informasi dikarenakan mereka tidak mengetahui secara pasti subjek atau permasalahan yang dicari.

Dalam menggunakan strategi penelusuran, selain memahami adanya beberapa macam jenis strategi seperti boolean logic, power searching, limiting searches, dan truncation, para pencari informasi juga harus mengetahui permasalahan atau subjek yang diinginkan. Hal tersebut untuk lebih memfokuskan pencarian yang berhubungan atau mengandung makna seperti yang diketikkan pada tool box searching. Itu artinya banyak responden yang tidak mengetahui secara pasti apa yang dibutuhkan. Hal tersebut sejalan dengan pemikiran Hary dan Dewdney yang dikutip oleh Suadi dan Makmur (2015:20) menjelaskan salah satu hambatan dalam mencari informasi adalah tidak mengetahui kebutuhan informasi. Sehingga responden masih merabaraba masalah. Tentu saja hal tersebut membuat proses penelusuran semakin lama meskipun telah menggunakan strategi maupun yang belum.

Faktor lain yang mempengaruhi kemampuan seseorang dalam menelusur adalah merumuskan kata kunci. Kata kunci adalah salah satu strategi yang dapat memudahkan seseorang saat berselancar di internet. Ternyata merumuskan kata kunci tidak semudah itu, karena seseorang harus memahami dengan baik subjek atau permasalahan yang sebenarnya dicari. Kata kunci yang baik dapat mengandung satu kata atau bahkan frase yang mewakili suatu topik permasalahan. Misalnya seseorang sedang mencari artikel mengenai permasalahan restorasi gambut dan kelola lahan di daerah Kalimantan Barat agar tidak terbakar. Berdasarkan permasalahan tersebut, seorang pencari informasi dapat merumuskan kata kunci seperti "gambut", "gambut Kalimantan Barat", "lahan gambut", "restorasi gambut", dan lain sebagainya. Jika dikombinasikan dengan strategi penelusuran, sebagai contoh maka seorang pencari informasi dapat mengetikkan kata kunci berikut: "restorasi gambut AND Kalimantan Barat". 
DOI: 10.26418/jvip.v11i2.33040

Saat melakukan penelusuran, kata kunci yang dipilih harus berhubungan dengan titik akses (titik pendekatan) agar informasi yang diinginkan dapat terpanggil dengan cepat dan tepat. Titik akses yang dimaksud terdiri dari nama pengarang, subjek, dan judul. Berdasarkan hasil penelitian ini diketahui bahwa kata kunci yang berhubungan dengan titik akses yang paling sering digunakan oleh pencari informasi melalui laman e-resources.perpusnas.go.id adalah

Gambar 2. Titik akses yang digunakan

Mereka meyakini bahwa dengan menelusur menggunakan pendekatan subjek akan memperoleh artikel yang relevan. Subjek suatu permasalahan dapat mewakili tingkat pemahaman maupun pengetahuan seseorang dalam mengenali hal yang ingin dicarinya saat melakukan penelusuran. Ketika sudah mengetahui subjek masalah yang diinginkan, pencari informasi seharusnya sudah mengetahui lokasi akses yang tepat untuk memenuhi kebutuhan informasinya. Salah satunya dengan memilih perpustakaan atau tempat buku sebagai pilihan lokasi yang tepat untuk mendapat koleksi jika informasi yang diinginkan dalam bentuk tercetak. Sebaliknya jika informasi yang diinginkan tersedia dalam bentuk elektronik maka perlu memilih pangkalan data terpercaya, dengan keyakinan bahwa pencari informasi akan memperoleh informasi yang sesuai dengan kebutuhannya dan memenuhi kriteria kualitas informasi.

Dalam kasus penelitian ini yang menjadi obyek penelitian adalah pangkalan data terpilih milik pemerintah RI yang dapat diakses secara
Vol 11, No 2 (2019)- Atiqa Nur Latifa Hanum

bebas oleh masyarakat umum pada laman eresources.perpusnas.go.id. Layanan informasi online tersebut memberikan kemudahan akses dan waktu akses yang fleksibel sehingga pencari informasi dapat mengaksesnya kapan saja tanpa dibatasi ruang dan waktu. Informasi yang ada di dalamnya juga memenuhi kriteria informasi yang berkualitas sehingga pangkalan data ini tepat untuk digunakan sebagai referensi belajar siapapun yang membutuhkan informasi ilmiah berkualitas. Namun tidak semua subjek dapat ditemui pada layanan e-resources PNRI, akan tetapi masyarakat tetap dapat mencari informasi yang berhubungan atau berkaitan dengan subjek yang diinginkan.

Banyak diantara masyarakat pengguna layanan e-resources adalah para mahasiswa. Selain karena informasinya terpercaya, informasi yang tersedia juga mutakhir sehingga baik dijadikan sebagai bahan bacaan untuk membantu mereka belajar dan menyelesaikan tugas perkuliahan. Hasil penelitian menunjukkan bahwa alasan para responden melakukan pencarian informasi pada portal e-resources PNRI karena memiliki keabsahan konten dan juga informasinya yang mutakhir.

Saat melakukan pemanfaatan layanan eresources.perpusnas.go.id tersedia beberapa jenis koleksi. Siapapun bebas memilih jenis koleksi yang ada sesuai kebutuhan. Koleksi yang ada sudah terjamin keilmiahan informasinya sehingga sangat diminati oleh pencari informasi khususnya dari lingkungan akademik yang selalu membutuhkan referensi ilmiah untuk memudahkan pekerjaan mereka. Berikut hasil olah data pada penelitian ini:

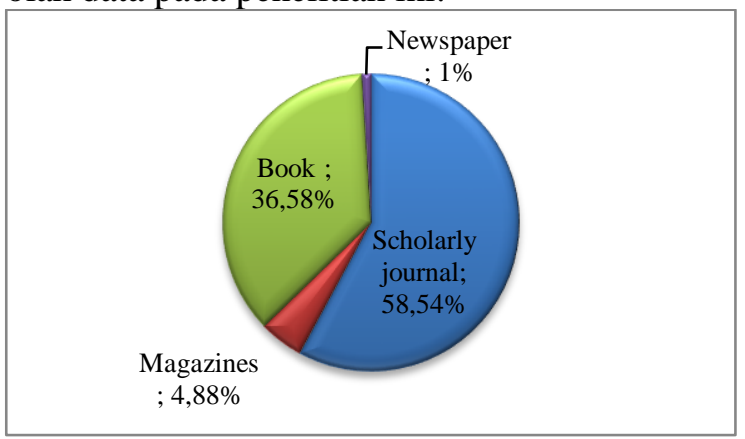

Gambar 3. Jenis koleksi yang diakses

website: http://jurnal.untan.ac.id/index.php/jvip email: jurnalvisi@untan.ac.id 
Sebanyak 58,54\% responden pada penelitian ini mencari jurnal ilmiah pada saat mengakses e-resources. Bagi mereka, jurnal merupakan salah satu referensi ilmiah yang mutakhir dari segi kebaruan informasinya. Tidak hanya itu, jurnal juga memberikan informasi yang lengkap dan tuntas sehingga yang dibutuhkan oleh mereka dalam menyelesaikan tugas perkuliahan terbantu oleh adanya jurnal sesuai dengan subjek masalah yang diinginkan para mahasiswa.

Jurnal ilmiah merupakan salah satu karya ilmiah yang berisi sejumlah artikel yang diterbitkan secara teratur dan berkala dengan tujuan untuk menyebarkan pengetahuan hasil dari penelitian atau temuan baru. Jadi, jurnal merupakan media komunikasi ilmiah yang bermanfaat bagi pengembangan ilmu pengetahuan. Dibandingkan dengan buku, jurnal memuat banyak informasi mengenai suatu topik dimana masing-masing artikel membahas fokus masalah yang berbeda-beda dengan artikel lainnya. Artinya antara artikel satu dengan artikel lainnya dalam satu jurnal tidak saling terkait atau berhubungan. Berbeda dengan buku, antarbab memiliki hubungan atau terkait sehingga membentuk satu kesatuan informasi yang utuh. Nilai informasinya lebih lengkap buku dan lebih mendalam buku jika dibandingkan dengan jurnal. Hanya saja dari kemutakhiran isi informasinya, jurnal merupakan salah satu referensi yang paling update dibandingkan buku maupun majalah.

Berdasarkan tabel 4 diketahui bahwa 70,73\% responden setelah menemukan dokumen hasil penelusuran pada portal eresources.perpusnas.go.id adalah untuk membandingkan temuan tersebut dengan temuan mereka yang sudah dan atau akan mereka peroleh dari pangkalan data lain. Tentu saja dokumen yang diperoleh tersebut sudah sesuai dengan topik yang dibutuhkan. Namun adakalanya mereka membutuhkan banyak referensi untuk membuat data semakin banyak sehingga informasi tersebut dimanfaatkan untuk belajar dan menyelesaikan tugas mereka semakin lengkap dengan data temuan dan usalan yang lebih mendalam serta jelas.

Penelitian ini juga menggali informasi mengenai hasil relevansi dari segi manfaat prediktif yang artinya setelah mereka memperoleh dokumen, maka mereka akan memanfaatkannya di kemudian hari. Berikut ini hasil penelitiannya:

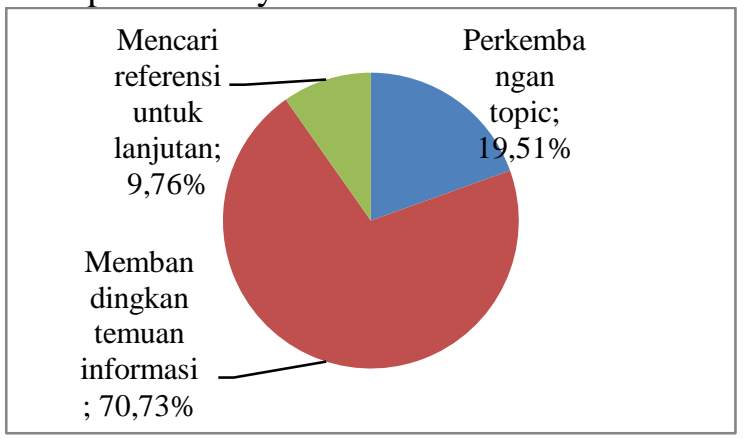

\section{Gambar 4. Relevansi hasil temuan}

Tidak semua responden melakukan hal tersebut, dalam kasus penelitian ini sebanyak $29,27 \%$ responden justru mengakses $e$-resources sebagai tahapan investigasi topik terkini dan akan mempergunakan topik yang sedang tren tersebut sebagai referensi untuk pengembangan di bidang keilmuan yang mereka tekuni. Dalam arti kata lain, tindakan mereka tersebut dikategorikan sebagai penelusuran lanjutan dimana pada tahapan tersebut tidak langsung memanfaatkan dokumen hasil temuan tetapi memprediksi ke depannya bahwa referensi akan dipergunakan untuk keperluan yang akan datang guna mengembangkan ilmu pengetahuan.

Berbeda dengan dokumen lainnya yang bisa ditemukan di pangkalan data bebas lainnya, baik yang berbayar maupun yang tidak, $e$ resources memberikan jaminan keabsahan informasi yang diperoleh. Artinya informasi yang disajikan dapat dipertanggungjawabkan. Setiap muatan artikel di dalam jurnal, ataupun buku, dan majalah memiliki autorisasi atau kepengarangan. Sehingga isi informasinya sudah jelas dari sumber yang dipercaya, ditinjau ulang, hingga keahlian bidang ataupun instansi penulis juga diketahui secara jelas. Oleh sebab itu,

website: http://jurnal.untan.ac.id/index.php/jvip email: jurnalvisi@untan.ac.id 
DOI: $10.26418 /$ jvip.v11i2.33040

koleksi yang ada di e-resources layak untuk didayagunakan untuk kepentingan pendidikan.

Hal tersebut yang menyebabkan mahasiswa percaya dan mengakses e-resources, salah satunya karena sumber informasinya terpercaya dan memiliki banyak varian subjek keilmuan. Ini menjadi daya tarik tersendiri bagi kaum pelajar, karena mudah diakses dan dapat pula diunduh. Namun beberapa responden menerangkan bahwa ada beberapa dokumen yang mereka inginkan tidak dapat diunduh bahkan tidak dapat dibaca secara penuh di laman website e-resources PNRI. Tidak dapat dipungkiri bila hal tersebut terjadi, karena kembali lagi pada vendor yang menyediakan artikel jurnal atau buku tersebut apakah membuka izin akses secara bebas kepada instansi mitra yang berlangganan jurnal mereka atau tidak.

\section{SIMPULAN DAN SARAN Simpulan}

Berdasarkan hasil dan pembahasan tersebut, hipotesis terbukti bahwa ada hubungan antara kemampuan mahasiswa dalam menelusur dan pangkalan data yang digunakan dengan relevansi hasil yang ditemukan. Tingkat kemampuan mahasiswa dalam menelusur mempengaruhi kecepatan, ketepatan, serta kemudahan mereka saat melakukan penelusuran. Namun yang menjadi kendalanya, masih sulitnya mahasiswa merumuskan kata kunci saat melakukan penelusuran dan hal ini berdampak pada ketepatan menemukan topik yang diinginkan. Di sisi lain, penelitian ini membuktikan bahwa dengan menggunakan strategi penelusuran akan memudahkan mereka menemukan informasi yang relevan tentunya sesuai dengan yang diharapkan. Akan tetapi faktor besar yang membuat proses menemukan informasi menjadi relatif lebih lama dikarenakan kurangnya kemampuan mahasiswa dalam memecah kata kunci permasalahan yang akan dicari. Banyak diantara mahasiswa yang masih merasa sulit untuk merumuskannya karena keterbatasan pemahaman dan pengetahuan
Vol 11, No 2 (2019)- Atiqa Nur Latifa Hanum

mengenai topik yang dicari. Sehingga untuk memaksimalkan kemampuan menelusur, seseorang perlu memahami beberapa teknik strategi penelusuran, memahami inti dari topik permasalahan yang sedang dibutuhkan sehingga dapat membuat kata kunci yang mewakili topik tersebut, memahami karakteristik sumber informasi digital, pengecekan kredibilitas sumber, mengetahui subjek-subjek yang dimiliki oleh sebuah jurnal, dan juga memahami jenis dokumen yang diinginkan. Jika beberapa hal tersebut sudah dipahami dan dikuasai maka mudah bagi seseorang menemukan informasi yang relevan pada laman portal e-resources PNRI maupun database-database online lainnya dalam waktu yang singkat dengan hasil temuan yang memuaskan.

\section{Saran}

Di era keterbukaan informasi sangat memungkinkan seseorang dapat mengakses informasi dari segala media dalam berbagai bentuk sajian informasi. Namun yang perlu dipelajari dan dilatih adalah membiasakan diri untuk menggunakan strategi penelusuran dan memilih database online terpercaya saat akan menelusur informasi untuk menghindari kemungkinan mendapatkan informasi hoax atau informasi yang tidak dapat dipertanggungjawabkan keabsahannya. Salah satu cara meminimalisir kemungkinan tersebut dengan memanfaatkan portal e-resources PNRI untuk mendapatkan artikel jurnal dan buku sebagai referensi belajar.

\section{DAFTAR RUJUKAN}

Al-Bahra bin Ladjmudin.(2005).Analisis dan Desain Sistem Informasi.Yogyakarta: Graha Ilmu

Agus Mulyanto.(2009).Sistem Informasi: aplikasi dan konsep. Yogyakarta: Pustaka Pelajar.

Anas Sudijono.(2009).Pengantar Statistik Pendidikan. Jakarta: Rajagrafindo

website: http://jurnal.untan.ac.id/index.php/jvip email: jurnalvisi@untan.ac.id 
DOI: 10.26418/jvip.v11i2.33040

Bambang Hartono.(2013).Sistem Manajemen Berbasis Komputer. Jakarta: Rineka Cipta

Depi Suadi dan Testiani Makmur.(2015). Revolusi Sumber Informasi Digital. Yogyakarta: Bulaksumur Empat.

Imam Ghozali.(2018).Aplikasi Analisis Multivariate dengan Program IBM SPSS 25. Edisi 9.Semarang: Universitas Diponegoro

John W. Creswell.(2016).Research Design: pendekatan metode kualitatif, kuantitatif, dan campuran. Edisi 4. Pustaka Pelajar: Yogyakarta.

Laksmi dan Kiki Fauziah.(2016).Budaya Informasi. Jakarta:ISIPII Press

Latan, Hengky dan Imam Ghozali. 2012. Partial Least Squares Konsep, Teknik dan Aplikasi Menggunakan Program SmartPLS 2.0 M3. Semarang: Badan Penerbit Universitas Diponegoro
Vol 11, No 2 (2019)- Atiqa Nur Latifa Hanum

Pawit M. Yusuf dan Priyo Subekti.(2010). Teori dan Praktik Penelusuran Informasi. Jakarta: Prenada Media Group

Resita Pristiana Dewi dan Lilis Ardini.(2013).Pengaruh Keakuratan, Tepat Waktu, Keandalan, dan Relevansi Terhadap Kepuasan Pengguna Sistem Informasi Akutansi. Jurnal Ilmu \& Riset Akuntansi, Vol.2 No.5

Skills for Learning.(2018). Guide to Evaluating Information [online]. Wolverhampton: University of Wolverhampton [accessed 23, April 2018]. Available at [<http://www.wlv.ac.uk/skills>]

Sufren dan Natanel.(2013).Mahir Menggunakan SPSS secara Otodidak.Jakarta:Elex Media Computindo 